\title{
A farewell to the market! Constructing a Carolingian subsistence economy east of the Rhine*
}

\author{
Weg mit dem Markt! \\ Versuch über eine karolingische Subsistenzökonomie \\ östlich des Rheins
}

\author{
Adieu au marché! \\ Naissance d'une économie de subsistance à l'époque carolingienne \\ à l'est du Rhin
}

Thomas Meier

Current studies in environmental archaeology normally argue from a rationalist point of view. The discussion is partly stuck into theoretical concepts, such as the optimal forager of paleolithic and mesolithic times. It is also more implicit, such as the archaeological imaginations of the medieval farmers trying to optimize their yields by applying new techniques of agriculture. This kind of economic rationality is even applied to animals and plants - of course not in theory, but in the daily use of scientific language. As we all know, the use of language creates realities. In these spoken and written realities, pigs and grasses select specific fodder or certain soils for better or optimal nutrition; they even change colour, size and behaviour to be more attractive for sexual partners and to optimize their chance of reproduction.

Such language and such reasoning honours the narratives of progress and rationality - more precisely the narrative of a specific kind of economic rationality: It is the logic of Adam Smith, Charles Darwin and the Olympic Games, the logic of competition, stress and survival, the logic of the New Economy, eternal growth and the logic of the market.

This logic is the dominant paradigm when it comes to questions of economy and social behaviour during the last one-and-a-half centuries. Today some colleagues have completely internalised the narra-

\footnotetext{
* This paper briefly summarises some basic points of the second part of my habilitation thesis „Sozialstruktur und Wirtschaftsweise im frühmittelalterlichen Südbayern. Das Beispiel der Siedlungen Kelheim-Kanal I und Unterigling-Loibachanger", handed in at the University of Kiel in October 2007. It is based on a research project „Ökosystem, Sozialstruktur und Wirtschaftsweise im mittelalterlichen Altbaiern“ generously funded by the VolkswagenStiftung in 2003-2006, to whom I am more than grateful!
}

tive so that to them it seems to be a trans-cultural anthropological constant, they proclaim it to be innate, "natural“. This proclamation of "naturalness“ can sometimes quite obviously be a discursive means for excluding questions and competing ideas, but in other cases proponents really seem to be convinced that the logic of the market is the only possible way humans can think and live, or at least live properly.

It has been three generations since the Belgian historian Henri Pirenne measured the changes of the lateantique and the early medieval economy against the criterion of long distance trade. While he saw flourishing shipping traffic connecting all parts of the mediterranean mare nostrum during antiquity, the Muslim conquest of the Near Eastern and southern mediterranean coast during the 7 th and early 8th century caused this traffic to break down and push Christian Europe aside to the north, becoming an inland culture with the manorial system as a closed agrarian economy without towns, merchants and trade. Basically it was the Muslims who turned antiquity into the middle ages. Pirenne could not speak of this vanishing long distance trade other than in terms of loss and decline (Pirenne 1933, 9ff; 1937). ${ }^{1}$

Pirenne's 'thesis' became the dominant narrative of the following decades, and during the lucky and selfpleasing boom of the 1960s Georges Duby elaborated

\footnotetext{
For the history of criticism on Pirenne, see Hodges/Whitehouse 1983, 1ff; Hodges 2000, 16ff; Verhulst 2002, 2-5. A thorough, source-based evaluation of late antique and early medieval long-distance trade is offered by Michael McCormick (2001). He, as well as Richard Hodges and David Whitehouse (1983), convincingly show that Pirenne's thesis concerning the breakdown of mediterranean shipping and trade in Carolingian times is wrong.
} 
Pirenne's sketch to give an even more morbid picture of this period of disaster. On basis of Carolingian urbaria, Duby proclaimed that the people of the Carolingian empire had to endure starvation throughout their lives - which were short enough, because of the total lack of a market. Basically they died almost immediately after birth and in between they had to work the soil, entirely lacking iron tools, virtually with their finger nails or at best with wooden implements. Likewise husbandry was hopelessly underdeveloped, therefore manure was lacking and yields were low. Conditions were further diminished by rents. Only a small part of the land was cultivated by slaves of the landlords, as freemen were even more underdeveloped in their technical abilities (Duby 1962, 1, 59ff; 1973, 20ff). This image of a really deeply dark middle ages was supported by studies that focussed on incessant famines (e.g. Verhulst 1965, 180-189; Riché 1963, 294f) and by anthropological analyses detecting signs of starvation among one third or more of each population-at-death (e.g. Ziegelmayer 1988, esp. 257; for a critical assessment, see Haidle 1997). The reader was left alone to consider for themselves how such bands of rotten slaves were able to build Aix-la-Chapelle, to manufacture the elegant works of Carolingian court-art, and to conquer fully one half of Europe - but no one wondered. For Pirenne, Duby and others (e.g. Riché 1963, 159-164; Fossier 1981, esp. 267ff; Chapelot/Fossier 1980, 24-30; Kuchenbuch 1978, 289-292; Fichtenau 1994, 442444), ${ }^{2}$ including their academic and popular readers aduring the hey-days of system struggle between capitalism and socialism, economies other than market economies could only be considered to be disastrous!

The image of a starving early middle ages, furnished with villages resembling a place in Dante's Inferno and an early type of desolate socialist command economy. ${ }^{3}$ The image did not remain undisputed for long:

- Raymond Delatouche pointed to the fact that agrarian implements were stored at the bondsmen's farmsteads instead of the manor and consequently were not listed in the urbaria. Duby was therefore wrong to deduce from these texts that there was a lack of tools (Delatouche 1977, esp. 78-80; Elmshäuser Hedwig 1993, 199-201).

- Michel Rouche calculated that the calorific intake of 'normal' Carolingian food ratios was between $4.000 \mathrm{kcal}$ and $7.000 \mathrm{kcal}$, thereby proposing that

\footnotetext{
For a summary of the discussion cf. Elmshäuser/Hedwig 1993, 199-201.

'Selon qu'on lit Robert Fossier ou Raymonde Delatouche, le village carolingien paraît être tantôt un site de l'enfer de Dante, où des êtres haves et dépenaillés grattent le sol avec des bâtons en guise de labour, tantôt une préfiguration des communes rurales de la Chine contemporaine, où l'entassement des hommes parait la source intarissable de rendements sans cesse croissants', Devroey 1985, $475 f$.
}

Carolingian famine was no physiological starvation, but rather a fear of hunger. This fear was a constant concern for the Carolingian upper class used to very large amounts of food (Rouche 1973; Devroey 1987). ${ }^{4}$

- With regard to early modern famines of the Ancien Régime Pierre Chaunu dryly commented that it was hard to die of hunger on the coast, where you could fish; that it was hard to die of hunger where there are groves, trees and shrubs; and that it was not so easy to die of hunger where there are woods (Chaunu $1970,232)$. It was quite unlikely that these facets did not apply to Carolingian times as well.

- Physiological signs of deficient nutrition left on the skeletal remains can be caused by rich but unbalanced food, as well as individual health, parasites and/or cultural modes of living, such as lacking sunlight. Any inference in relation to subsistence strategies of a society drawn from diagnostic indicators on individual skeletons is speculative in the extreme.

It was Jean-Pierre Devroey, who sketched a different image of a prosperous Carolingian empire, a first phase of economic growth (Devroey 1985). His key argument was for a tremendous expansion of the settlement area (Landesausbau) up to 1000AD, including clearances of huge forests and the development of most marginal areas of the Carolingian empire. The expansion required a demographic growth, which in turn needed a highly efficient economy (cf. Abel 1967, 25ff; Toubert 1988; Lohrmann 1988; Verhulst 2002, 2328). Contrary to Duby, who regarded the freemen to be even more underdeveloped than the manors, Devroey believed that it was these free or at least independent farmers of a decomposing manorial system, who were the backbone of the successful Carolingian economy (Devroey 2006, 374f). Their private entrepreneurial initiative was what sustained the Carolingian boom years (cf. Doehaerd 1971, 238ff). Famines were now considered to have been regional events at the core of the empire, where population grew faster than agrarian production: "they [famines] should perhaps [...] be seen as "accidents" of expansion" (Verhulst 2002, 71). With respect to the Pirenne-thesis, and contrary to it, Devroey decides for successful Carolingian markets and a money-economy.

Disregarding decline or growth for Devroey the yardstick for describing and evaluating Carolingian economy was still the market system. Like Pirenne and Duby, he was trapped by the thinking of „baisse“

\footnotetext{
Even if we accept that units are not as easily calculated as Rouche had (Hocquet 1985), and calorie-ratios were somewhat lower, they still remain remarkably high and validate the argument.
} 


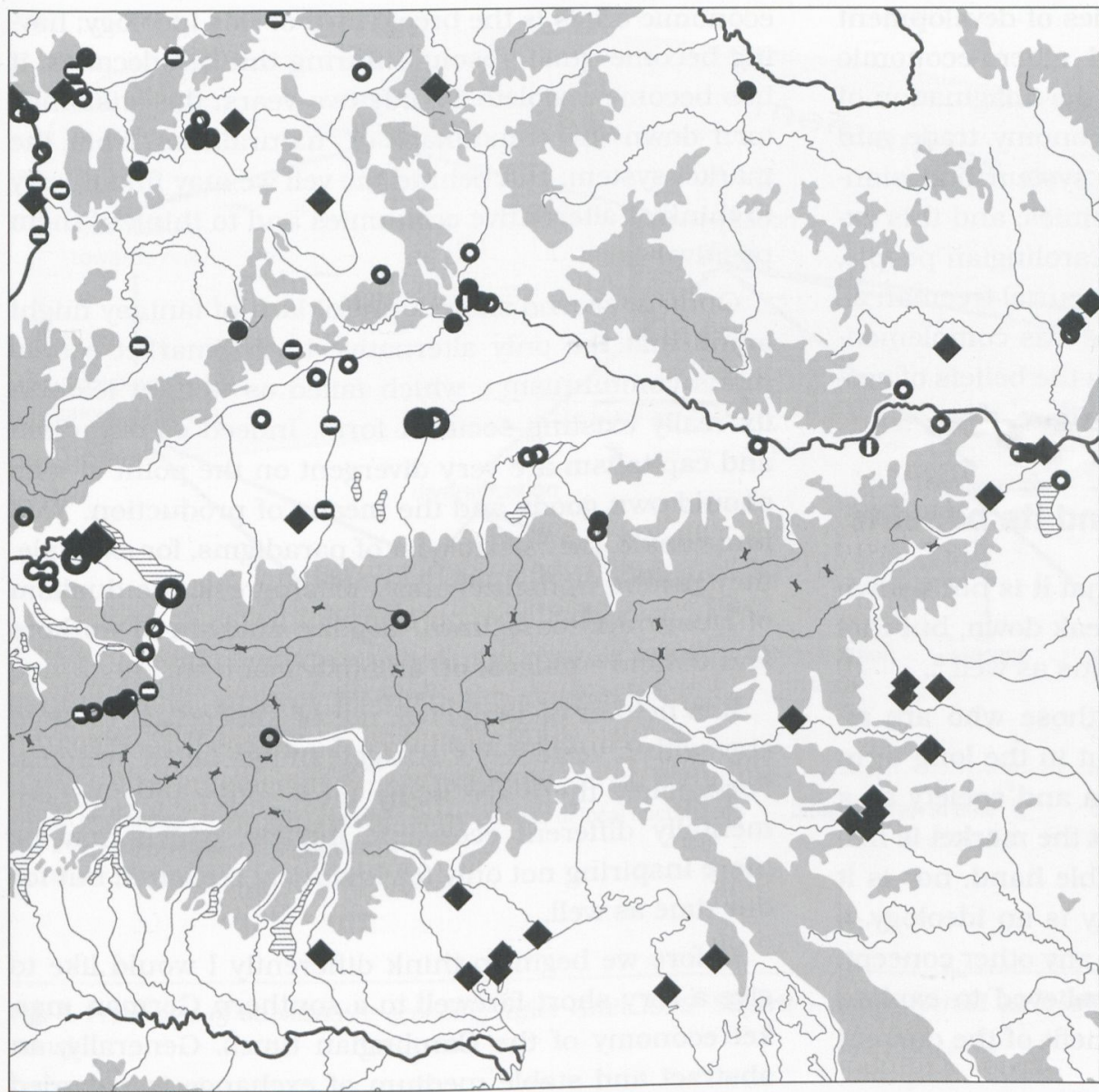

Fig. 1. Distribution of Carolingian coins in southern Germany and the eastern Alps.

Circle with vertical line: coins from the mint of Regensburg; circle with horizontal line: coin from Frankish mints west of the Rhine; circle with dot: coin from Italian mints (mapped only north of the main-crest of the Alps); rhombus: coins from eastern mints (8th-10th century); enlarged symbol: hoard.

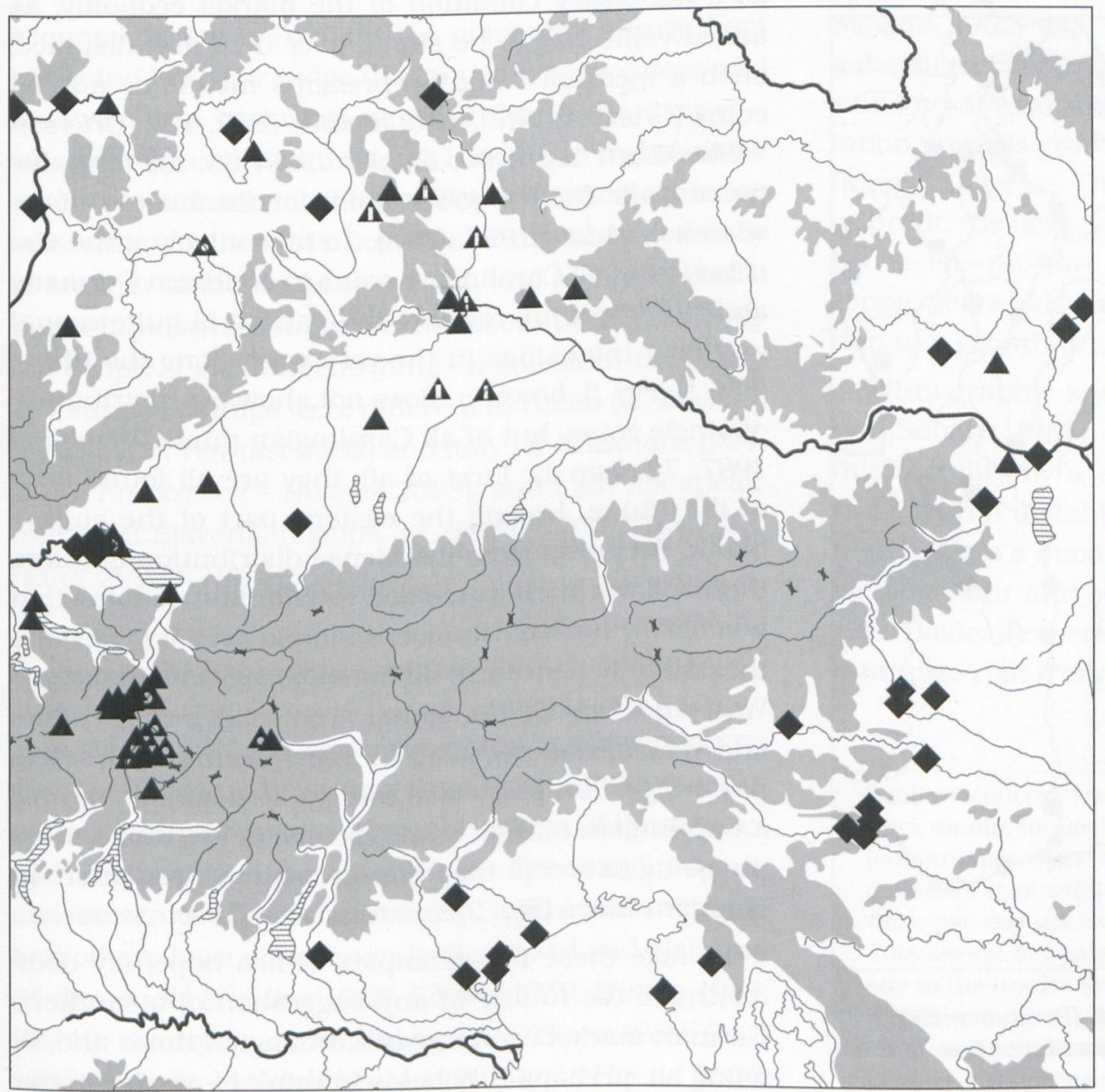

Fig. 2. Distribution of coins of Ottonian times in southern Germany and the eastern Alps.

Triangle with vertical line: coins from the mint of Regensburg; triangle with dot: coin from Italian mints (mapped only north of the main-crest of the Alps); rhombus: coins from eastern mints (8th10th century): enlarged symbol: hoard. 
and „hausse“, in Braudel's long cycles of development (Braudel 1958), which transcended macro-economic theory into a rule of history, and in the imagination of historical progress towards urban economy, trade, and capitalism. To Duby, the manorial system had similar faults to socialist planned economies, and this explained the disastrous state of the Carolingian people, but Devroey's praise of the entrepreneurial freeman as warrantor of the Carolingian hausse was complementary, since both were firmly rooted in the beliefs of economical liberalism and individual welfare.

\section{The actual economic crisis and its benefits}

In recent years we have learned that it is not a privilege of non-market economies to break down, but that the market economy can be disastrous as well ...

I am explicitly not speaking of those who are affected immediately by this crisis, but in the long term this is very good news for academia and society as a whole. It now becomes apparent that the market is neither divine and guided by an invisible hand, nor is it natural. Rather the market economy is an ideology, a mode of economic thinking. As with any other concept, it becomes a problem when it is believed to explain and rule everything. For me, the benefit of the current

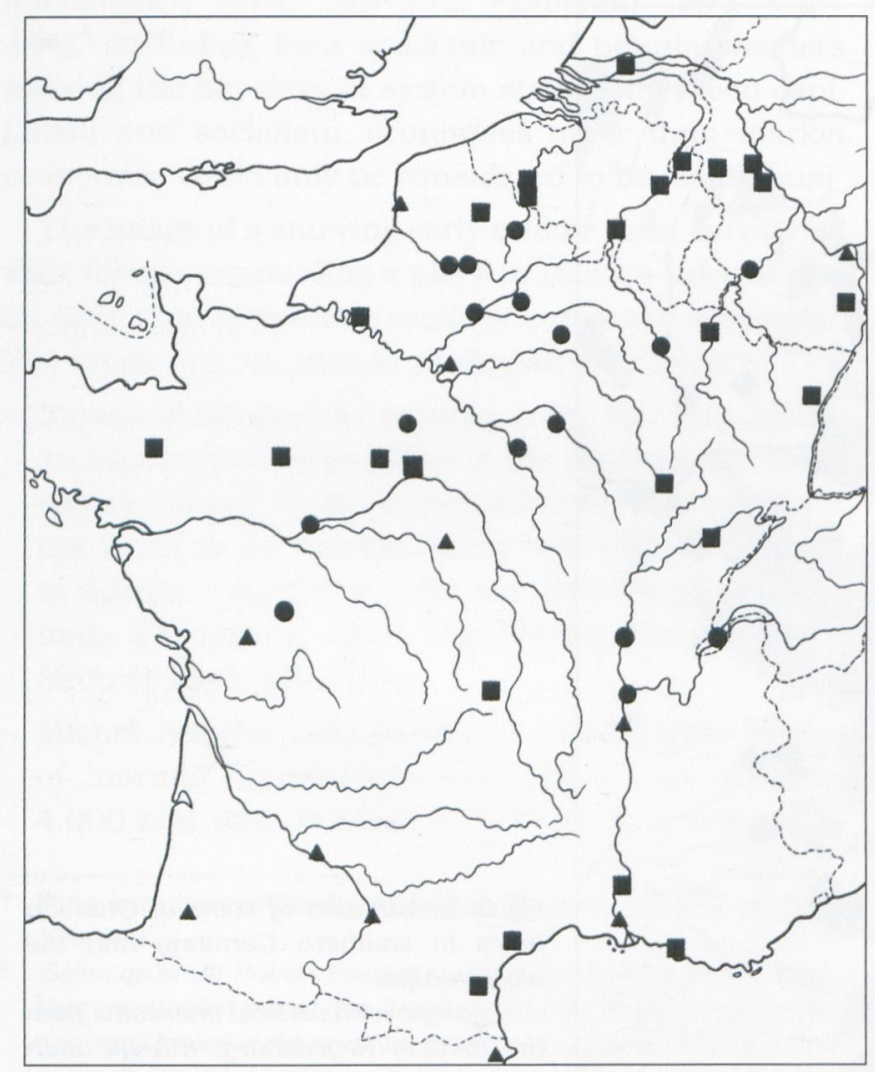

Fig. 3. Early Carolingian mints 752-814 (Berghaus 1987, 72 map 1).Circle: first account 752-768; quadrate: first account 768-793; triangle: first account 793-814. economic crisis is the breakdown of this ideology; having become quite absolute during the last decades, it has become obsolete in only two years; the crisis has torn down the camouflage of 'naturalness' from the market-system, and behind the veil we may find liberty to think of alternative economies and to think of them positively.

Only those who share a pitiful lack of fantasy might argue that the only alternative to the market economy is communism - which failed as well, at least in its really existing socialist form. Indeed communism and capitalism are very divergent on the point of who should own goods and the means of production. This issue aside, they share a lot of paradigms, for example, they believe in the necessity of progress, the dualism of labour and past-times, and the dualism of workers and owners - at least on an analytical level.

It is neither of analytical, nor of intellectual value to stay within yesterday's struggle of two failed systems. Fortunately there are many more alternative, fundamentally different economic models, which may be more inspiring not only for historical research, but for our time as well.

Before we begin to think differently I would like to give a very short farewell to a southern German market economy of the Carolingian times. Generally, an abstract and stable medium of exchange is regarded as a necessary condition of the market economy, as added value has to be stored over time and distance; such a medium could be precious metals or minted coins (Grierson 1959, 126; Bleiber 1982, 107; Grierson - Blackburn 1986, 96; Irsigler 1989, 58; for long distance trade Dilcher 1985, 399f; for the history of research cf. Adam 1996, 186f). To take a look at the distribution of all Carolingian coins in southern Germany and neighbouring regions, the pattern is quite casual and only intensifies in the very west along the Rhine (Fig. 1). Fig. 3, however, does not show the distribution of single coins, but of all Carolingian mints (Berghaus 1987, 72 map 1): First of all, they are all found west of the Rhine, leaving the eastern part of the empire blank. Secondly, from this dense distribution of mints there follows such a crowded distribution of coins that it is hardly possible to plot as simple dots. It is obvious that there is a striking difference between the regions West and East of the Rhine. The total lack of mints and very sparse account for coins clearly contradicts any suggestion that there ever existed something like a Carolingian market economy east of the Rhine, if we are going to accept the criterion of coin circulation. In Ottonian times (Fig. 2), matters turned even 'worse' ...

To take these few examples, it has hopefully demonstrated the futility of any suggestion of a southern German market economy in Carolingian times and, in doing so, perhaps this helps to think of an alternative 


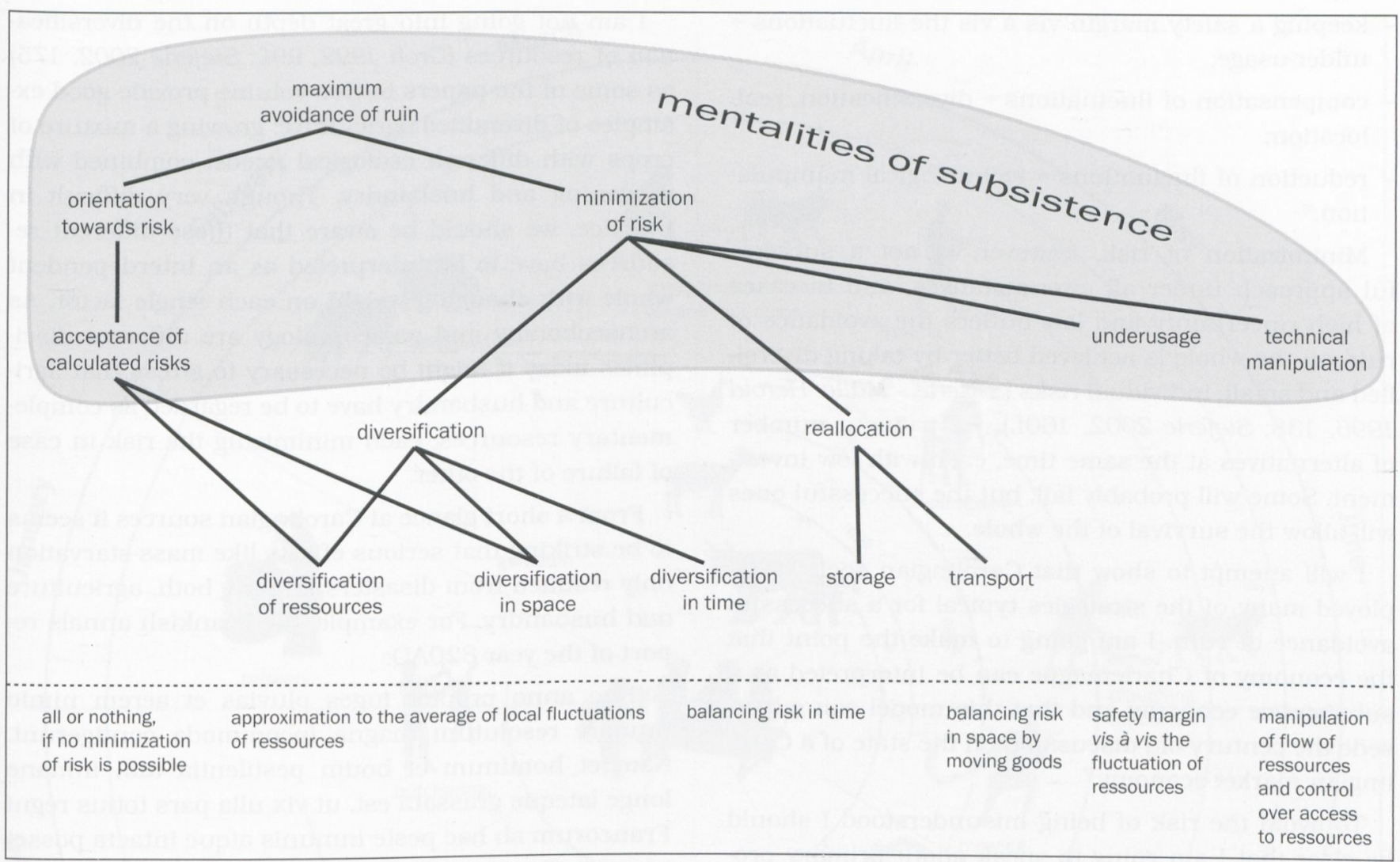

Fig. 4. Principles of subsistence economy (after Groh 1992; Sieferle - Müller-Herold 1996; Müller-Herold 2000; Sieferle 2002 with additions).

economic system. To make the point very clearly, I am not going to say or judge that any one economic model is closer to a historical truth of Carolingian times whatever this may be. Instead, I intend to test a model other than a market system against historical material, to assess whether it is possible to think successfully of another model in its own right, and to expect that it might have successfully met the needs of the Carolingian people. I am concentrating on southern Germany, as I suppose things were different in Gallia (cf. Devroey 1985; 2006; Verhulst 2002) and Italy (cf. Wickham 1994; 2005; Francovich - Hodges 2003), and I am not speaking about Slavonic regions (cf. Brather 2001, 164-182; Hardt 2008a; Hardt 2008b).

\section{Subsistence economy (Fig. 4)}

In this paper I am especially referring to a model created by ethnologist Marshall Sahlins in 1968. It participates a lot in the intellectual atmosphere of these years and was awarded the title 'Hippie Economy'. Historians Dieter Groh, Peter Sieferle, Ulrich Müller-Herold and others have subsequently discussed and elaborated the model (Sahlins 1968; Colson 1979; Minnis 1985, 32-42; Strategien 1986; Halstead - O'Shea 1989; Groh 1992; Sieferle - Müller-Herold 1996; Müller-Herold 2000;
Sieferle 2002, esp. 160-162). ${ }^{5}$ The basic principle of subsistence economy is its aim at stability: to have the same next year as you have this year. There is no orientation towards growth, either in wealth, demography, or in anything else. There is no idea such as added value or profit; the only point is to have enough of everything you need - to have only enough, but no more. In the hippie years this principle meant a conscious opposition to a growth-orientated market economy.

Ethnographic societies, studied by Sahlins and others (Sahlins 1968; e.g. Lee 1968; Mace 1993), achieve this stability by a strategy of maximum avoidance of ruin. Within a stable society with low uncertainty and high buffers a maximum avoidance of ruin is achieved by behaviour and action aimed at the minimization of risk. Basically there are three appropriate strategies to minimize risk from fluctuations of resources:

\footnotetext{
Sahlins' concept was heavily criticized on basis of empirical work among foragers of the northern hemisphere outside the (sub-)tropics. This criticism mainly concerns euphoric calculations that within a subsistence economy $4-5$ hours of work per day are sufficient to provide all necessities of life. This seems to apply only to regions of great ecological diversity in the tropics and sub-tropics, while in temperate zones it requires about 40 hours per week to fulfill these necessities. This criticism, however, does not affect the basic concepts of Sahlins' subsistence economy.
} 
- keeping a safety margin vis à vis the fluctuations = under-usage;

- compensation of fluctuations = diversification, reallocation;

- reduction of fluctuations $=$ technological manipulation. ${ }^{6}$

Minimization of risk, however, is not a successful approach under all circumstances, and in cases of high uncertainty and low buffers the avoidance of ruin on the whole is achieved better by taking diversified and small, individual risks (Sieferle - Müller-Herold 1996, 138; Sieferle 2002, 160f.), i.e. trying a number of alternatives at the same time, each with low investment. Some will probably fail, but the successful ones will allow the survival of the whole.

I will attempt to show that Carolingian society employed many of the strategies typical for a successful avoidance of ruin. I am going to make the point that the economy of Charlemagne can be interpreted as a subsistence economy and that this model can supersede the century-old discussion on the state of a Carolingian market economy. ${ }^{7}$

To avoid the risk of being misunderstood I should be clear that I am going to speak about primary production for the necessities of life only, and not about luxury goods. Luxury goods undoubtedly had a huge effect on Carolingian society, as they acted as material markers of prestige and thus constructed and displayed hierarchies. Philip Grierson already showed in 1959 that the distribution of prestige goods in the Carolingian empire can be well described and understood within the model of Marcel Mauss' gift exchangeeconomy (Mauss 1925; Grierson 1959; cf. Steuer 1999; Moreland 2000).

\section{Diversification of resources - agriculture and husbandry}

The most obvious option to avoid ruin is diversification in one or the other way. By diversification I mean any strategy dispersing production in a way that is minimizing risk. This may concern resources, time and space.

\footnotetext{
5 These three strategies should imply a tendency of historical steps as well (Sieferle - Müller-Herold 1996; Müller-Herold 2000, 26 Fig. 3). In my eyes such a story of progress from dependency on nature towards the manipulation of nature is not very helpful either for historical understanding or for reflection on our own state of human-environmental affairs.

7 Richard Hodges $(1989,13-15)$ has already referred to Sahlins thesis, but mainly concentrates on the development of towns and leaves aside the matters of primary production, while Chris Wickham $(1990,197 ; 1992,220-224)$ on the use of forests comes quite close to a Carolingian subsistence economy, but does not go into detail on this point as he is more interested in social history.
}

I am not going into great depth on the diversification of resources (Groh 1992, 99f; Sieferle 2002, 175) as some of the papers in this volume provide good examples of diversified agriculture: growing a mixture of crops with different ecological needs, combined with gardening and husbandry. Though very difficult in practice, we should be aware that these different resources have to be interpreted as an interdependent whole with changing weight on each single factor. As archaeobotany and palaeozoology are different disciplines today it might be necessary to stress that agriculture and husbandry have to be regarded as complementary resources, each minimizing the risk in case of failure of the other.

From a short glance at Carolingian sources it seems to be striking that serious effects like mass-starvation only resulted from disasters striking both, agriculture and husbandry. For example, the Frankish annals report of the year 820AD:

'Hoc anno propter iuges pluvias et aerem nimio humore resolutum magna incommoda contigerunt. Nam et hominum et boum pestilentia tam inmane longe lateque grassata est, ut vix ulla pars totius regni Francorum ab hac peste inmunis atque intacta posset inveniri. Frumenta quoque et legumina imbrium adsiduitate corrupta vel colligi non poterant vel collecta conputrescebant.' ('This year permanent rainfalls and too wet a climate caused great damage. Because an epidemic, which infected men and cattle, far and wide was so terribly furious that in the whole of the Frankish realm there was hardly a region to be found, which was free and uninfected of this epidemic. Crops and pulses as well were spoilt by the permanent rain and either could not be harvested or rotted after harvest.') (Annales regni Francorum ad a. 820, 154)

The following autumn was very rainy as well so that no winter crops can be sewn. The next year's winter was so fierce and long that even the great rivers of the Rhine and Danube were frozen; finally the breaking ice in the spring caused damage at the banks (by flooding of the fields?). In $823 \mathrm{AD}$, the harvest was again spoiled by hailstorms in many regions, and another epidemic hit men and animals. This is for the first time that the annals record starvation which, because the winter was intense again, lasted until the next year (Annales regni Francorum ad a. 821,157 ; ad a. 823 , 163f.; ad a. $824,164 f$.). This series of entries is most illuminating concerning the operating of a diversified agrarian economy. In 820 , rain spoils the crops short time before the harvest or else it would not have been so disastrous; additionally a pestilence affects husbandry. But no one refers to starvation at that moment, indicating that the diversification of resources were able to cope with the situation. But the weather continues to rain and no winter crops can be sown, and, therefore, 


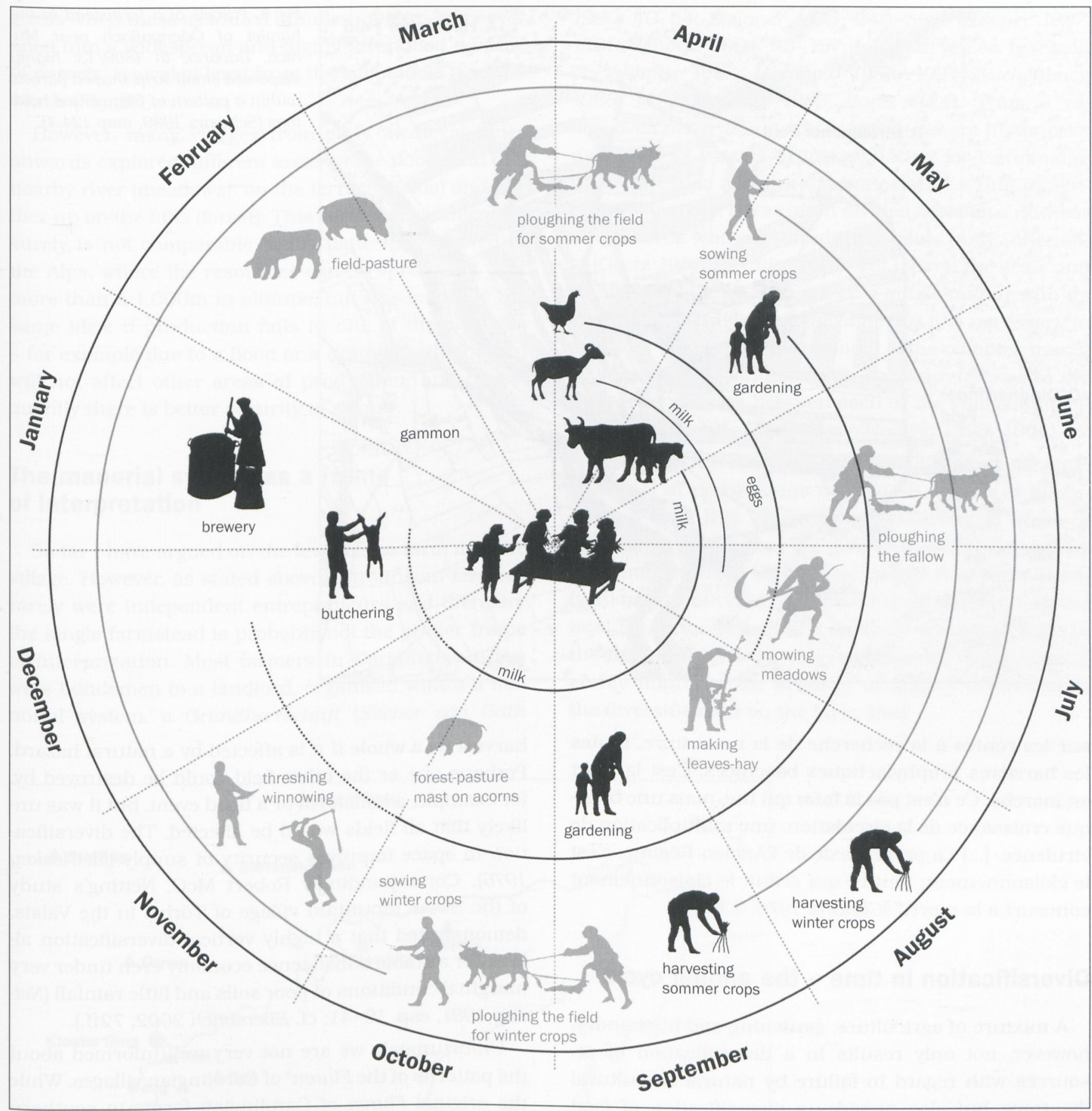

Fig. 5. Idealised annual cycle of food production in an agrarian unit (inspired and modified after Suter/Schibler 1996, fig. 7).

The inner circle shows activities of husbandry, followed by gardening; the outer circle shows agrarian activities. Black represents all components immediately producing food and the period of their availability, grey represents some components indirectly contributing to food production.

no bread crops could be expected for 821 . This is repeated in the autumn of 821 , when it is followed by a fierce winter, which finally spoiled all the crops, which had been sewn in spite of bad weather. In 822 there will have been no crops for bread again. The autumn of 822 was obviously better, but one must question whether there was enough seed left after three years of failed harvests. Stretched to the limit, it took only minor crop damage and a new(?) epidemic the next year to escalate the situation. It was now the fourth(!) year of continuous failure, and the diversification of resources had obviously failed totally. Yet it is not the hunger which kills, but epidemics among men. As Pierre Chaunu observes for the Ancient Régime:

"Alors, un des principaux dangers de la mauvaise récolte, le déclenchement de grandes migrations de misérables vers le point de secours, 20 à 30 p. 100 de marginaux réellement affamés, 10 p. 100 des affamés 


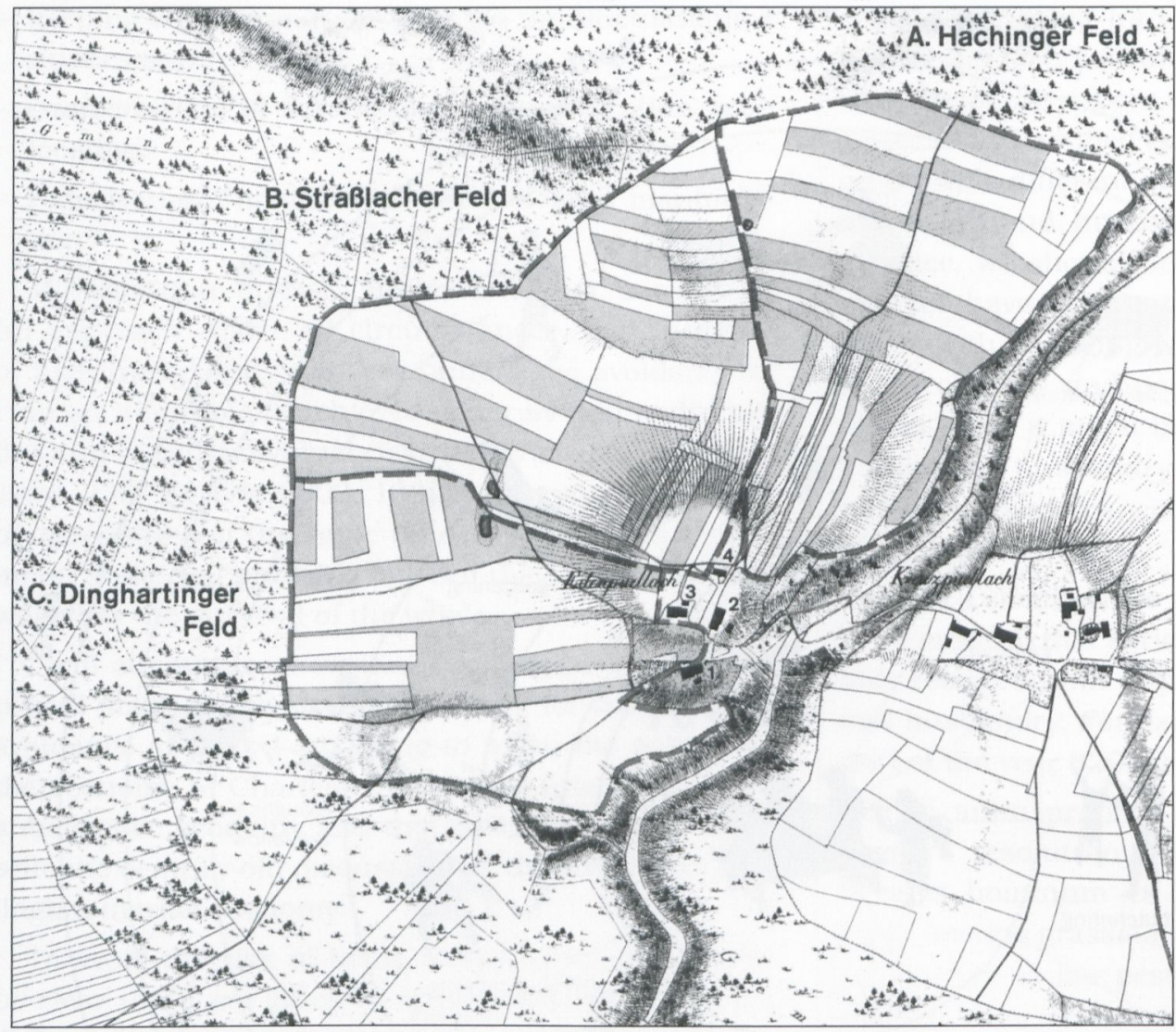

Fig. 6. Parcels of a farmstead in the hamlet of Ödenpullach near $\mathrm{Mu}$ nich, Bavaria, in 1809/13: highly dispersed small strip shaped parcels within a pattern of fragmented holdings (Schwarz 1989, map 124.4).

sur les routes à la recherche de la nourriture, toutes les barrières prophylactiques basculées, c'est la mort en marche. Ce n'est pas la faim qui tue, mais une brusque croissance de la circulation, une multiplication de virulence. [...] La prophylaxie de l'Ancien Régime, c'est le cloisonnement; tout ce qui réduit le cloisonnement concourt à la mort'." (Chaunu 1970, 232f).

\section{Diversification in time - the annual cycle}

A mixture of agriculture, gardening and husbandry, however, not only results in a diversification of resources with regard to failure by natural or cultural disasters, but also provides a diversification of food supply in the course of the year: The most critical time being the months between Advent and mid-March, an elaborate mixture of resources can shorten this time, e.g. by brewery and slaughter in mid-winter (Fig. 5).

\section{Diversification in space - the farm level}

A third way of diversification is a wide dispersal of resources in space. On the farm and village level agricultural areas were spread over some kilometres and if possible - across different ecotopes (Groh 1992, 99, 103-107; Sieferle 2002, 175). As Donald McCloskey has shown for the English open field system the wide spread of production areas minimizes the risk to the harvest as a whole if it is affected by a natural hazard. Perhaps one or the other field could be destroyed by, for example, a hailstorm or a flood event, but it was unlikely that all fields would be affected. The diversification in space improves security of supply (McCloskey 1976). Correspondingly Robert McC. Netting's study of the Swiss mountain village of Törbel in the Valais, demonstrated that a highly vertical diversification allows for a stable subsistence economy even under very marginal conditions of poor soils and little rainfall (Netting 1981, esp. 10-41; cf. Ebersbach 2002, 72ff.).

Unfortunately we are not very well informed about the patterns of the Fluren ${ }^{8}$ of Carolingian villages. While the original Fluren of Carolingian farms in southern Germany are normally reconstructed as compact bundles, without much argument (cf. Schwarz 1989, $199 \mathrm{ff}$. with amendments by Diepolder 2000), we may only

8 There is no English equivalent of the German term Flur. 'In agricultural geography the term "Flur" refers to the layout and shape of fields belonging to an agricultural community (Niemeier 1944, 58-59). Thus only those parts of the commonland that are periodically cultivated are included (for the duration of their cultivation) together with those parts of the commonland that are completely surrounded by privately used parcels. In contrast, the uncultivated parts of the commonland are excluded. Woodland falls within the "Flur" only if it is part of the agricultural area parcelled out. In the vernacular (in German) the word „Flur" is used for all open land of a settlement in contrast to woods.' (Uhlig 1967, E 36). 
guess when these assumed bundles split up and developed into a widespread and highly diversified mixture of parcels, typical at least from the late middle ages onwards (Fig. 6).

However, many villages from early medieval times onwards explored different areas in the floodplain of a nearby river (meadows), on the terrace (fields) and further up on the hills (forest). This vertical diversification surely is not comparable to the patterns observed in the Alps, where the resources can be spread out over more than a $1,000 \mathrm{~m}$ in altitude, but it is basically the same idea: if production fails in one of the ecotopes - for example due to a flood or a draught - the hazard will not affect other areas of production, and consequently there is better security of supply.

\section{The manorial system as a frame of interpretation}

So far I have argued on the level of the farm and the village. However, as stated above, Carolingian farmers rarely were independent entrepreneurs and therefore the single farmstead is probably not the proper frame of interpretation. Most farmers in Carolingian times were bondsmen to a landlord, organised within a manorial system, a Grundherrschaft (Slicher van Bath
1960, 40-54; Brunner 1973, 240-356; Rösener 1997, 112f.; Schulze 2004, 95-157; for a survey on research cf. Verhulst 1983; Morimoto 1988; 1994; Kuchenbuch 1988; 1997; Rösener 1989; Goetz 2001). Thus, a village even more than a single farmstead are historically meaningless frames of interpretation for Carolingian times, because a village did not exist as a unit of agricultural activity. It was often divided between a number of landlords who organized their lands quite differently (Goetz 1987; Verhulst 2002, 46f.). Even the scale and frame of reference may not be a single manor with its dependent farmsteads (villicatio), but it is necessary to consider the entire possession, i.e. the complex manorial system of a landlord with special reference to the interdependencies between each of the villications (cf. Preidel 1965, 10f.; Elmshäuser/Hedwig 1993, 400f.).

A striking feature of the manorial system is the wide dispersal of possessions over some dozens of kilometers at least (Fig. 7). Such a distribution of areas of production minimizes the risk to the total harvest by any single hazard. Maybe, one or the other farm or villication was affected, but it was very unlikely that the total manorial system of a landlord was impacted. On the manorial level the diversification in space considerably improves the security of supply compared to the diversification on the farm level.

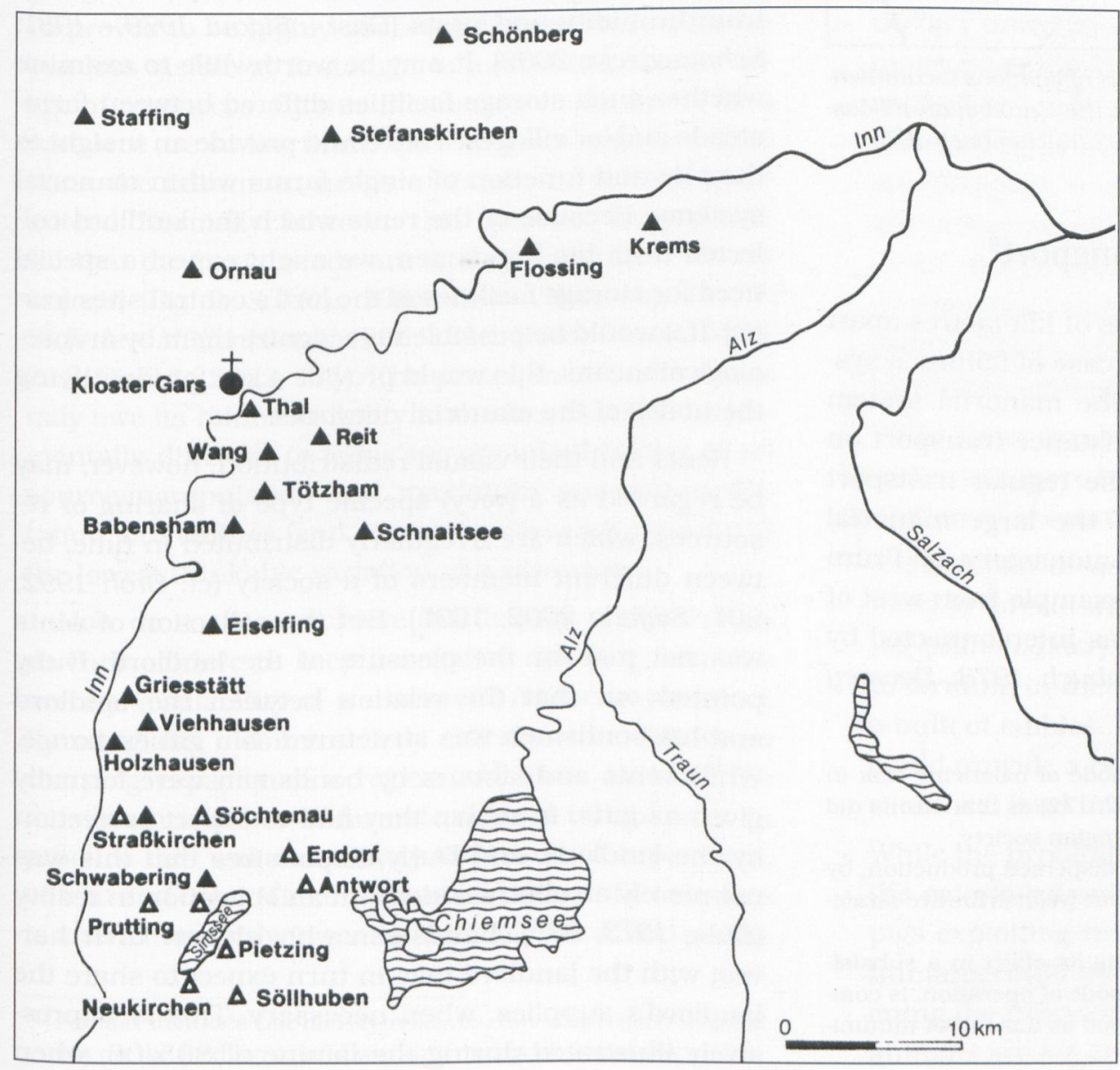

Fig. 7. The manorial possessions of the monastery of Gars in southeastern Bavaria in the 10th century (Störmer 1989, 383 map. 1). 


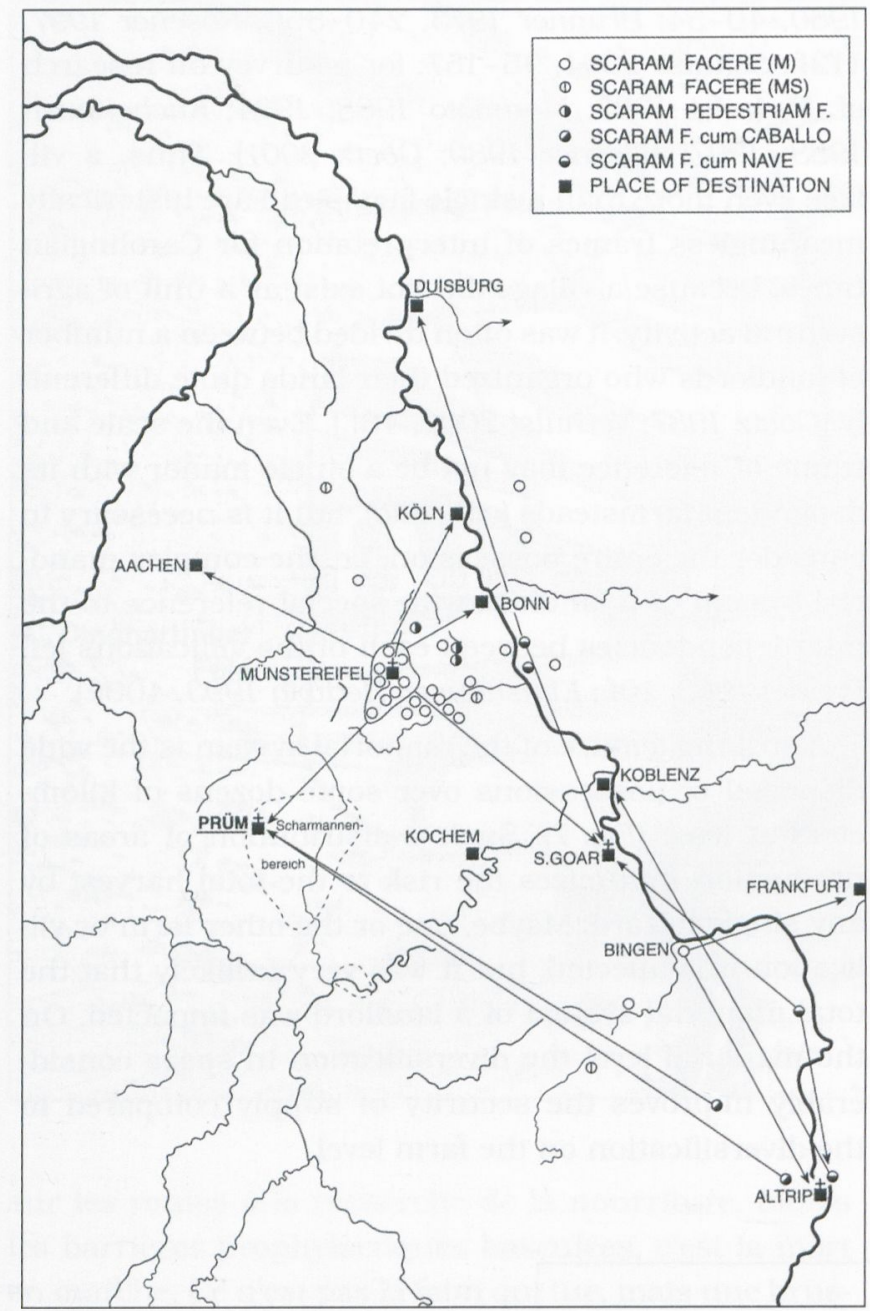

Fig. 8. Forms and distribution of transport obligations (Schardienste) within the manorial possessions of the Carolingian monastery of Prüm according to its Urbar of 893 (Kuchenbuch 1978).

\section{Reallocation in space - transport $^{9}$}

If possessions tens or hundreds of kilometres apart were to stand in for each other in case of failure, a system of reallocation was vital..$^{10}$ The manorial system was able to organize such long distance transport on a regular basis. ${ }^{11}$ For example, the regular transport obligations of the bondsmen of the large manorial possessions of the Carolingian monastery of Prüm are known (Fig. 8) - however an example from west of the Rhine. The entire complex was interconnected by a network of transports (Kuchenbuch 1978; Devroey

\footnotetext{
I do not consider migrations as a mode of balancing risk in space by moving people (Sieferle 2002, 172) as this means did not play any significant role in Carolingian society.

${ }^{10}$ If diversification is going to indicate dispersed production, by reallocation I mean non-productive but (re)distributive strategies.

11 This structure of transport, regarding its effect in a subsistence economy, but disregarding its mode of operation, is comparable to long-distance trade with food as a mean of minimization of risk (Sieferle 2002, 174f.).
}

1979). It was possible to shift food and other goods from one region to another, if there were local needs due to failures in harvest or epidemics. However the quotation from the Annales regni Francorum comes to our mind which notes the exceptional case of the years 820-824, when epidemic was almost everywhere. Only the most extreme circumstances with widespread failure in agriculture and husbandry led to a total shortage on the level of the manorial system. The internal transport system could not cope with this shortage, because food was missing everywhere and could not be reallocated within the manorial complex, which resulted in widespread famine.

\section{Reallocation in time - storage, rents and redistribution}

The flow of goods within a manorial system can be interpreted as reallocation not only in space, but also in time when considering storage. Storage implies a temporal reallocation by keeping resources from a period of surplus in case they are needed in a period of shortage (Sieferle 2002, 173).

With regard to the many small buildings of early medieval settlements, which probably were stores for crops of different kinds and hay, storage was highly diversified in space. Hypothetical reconstructions of such stores empasise raised floors in order to protect goods from humidity and pests (Gast - Sigaut 1979 - 1981; Schmaedecke 2002). It may be worthwhile to examine whether such storage facilities differed between farmsteads and/or villages. This could provide an insight to the role and function of single farms within manorial systems. Because of the rents which the landlord collected from his bondsmen, we might expect a special need for storage facilities at the lord's central sites (curtis). If it would be possible to recognize them by archaeological means, this would provide a key for identifying the nodes of the manorial networks.

Rents and their casual redistribution, however, may be regarded as a (very) specific type of sharing of resources, which are irregularly distributed in time, between different members of a society (cf. Groh 1992, 90f.; Sieferle 2002, 169f.). But the collection of rents was not just for the pleasure of the landlord. Duby pointed out that the relation between the landlord and his bondsmen was structured as a gift exchange. While rents and labours by bondsmen were formally given as gifts, in return they had to expect protection by the landlord, and Duby emphasizes that this was not merely an abstract idea, but an obligation in reality (Duby 1973, 67f.). Bondsmen who 'shared' their harvest with the landlord may in turn expect to share the landlord's supplies, when necessary. This is impressively illustrated during the famine of $805 / 06$, when 
Charlemagne ordered all landlords to feed their familiae: ${ }^{12}$

'Consideravimus itaque, ut praesente anno, quia per plurima loca fames valida esse videtur, ut omnes episcopi, abbates, abbatissae, obtimates et comites seu domestici et cuncti fideles qui beneficia regalia tam de rebus ecclesiae quamque et de reliquis habere videntur, unusquisque de suo beneficio suam familiam nutricare faciat, et de sua proprietate propriam familiam nutriat.' ('For this we consider that in the present year, as in many places a great famine can be observed, that all bishops, abbots, abbesses, nobles and earls as well as all members of the [royal] household and all faithful, who hold royal or ecclesiastical or any other feuds, each of them should feed his familia from his feuds and should feed his own familia from his [allodial] possessions.') (Capitulare Niumage [805/06] c. 18, 132; cf. Verhulst 1965, 187)

Thus rents, their storage and casual transport and redistribution in a manorial system were a function to equalize variations in production on a supra-regional level and in time.

\section{Under-usage and artificial shortage of resources}

Diversification and reallocation are quite obvious organisational means to avoid ruin, which in many cases proved to be highly successful. Even more effective but less visible at first sight is a structural under-usage of resources. By this means, the basic needs for a resource are so low that even with great negative variations the minimum needs of existence are still guaranteed. Normally, however, this resource is so plentiful that the basic needs are transgressed by a luxury margin (Fig. 9; Sahlins 1968; Groh 1992, esp. 74-77; Sieferle-Müller-Herold 1996, 139f.; Müller-Herold 2000, 24f.; Sieferle 2002, 171). The principle of under-usage may owe its minor visibility to the fact that it is fundamentally different to today's economic thinking of resource-manipulation and maximum resource-exploitation, but defines (and accepts) a carrying capacity at the lowest thinkable variation of a resource.

How do societies achieve this luxury margin? How do they achieve to keep a negative distance from the average availability of a resource? As far as we know, Carolingians did not strictly calculate the minimum carrying capacity of a region and then estimate the maximum number of farmsteads and inhabitants. In practice this was most likely the result of experience, of trial and error. The minimum variation of a resource is a strict line only in mathematical abstraction on the

\footnotetext{
${ }^{12}$ Familia includes not merely relatives, but all persons depend-
} ent on the lord living and working on his possessions.

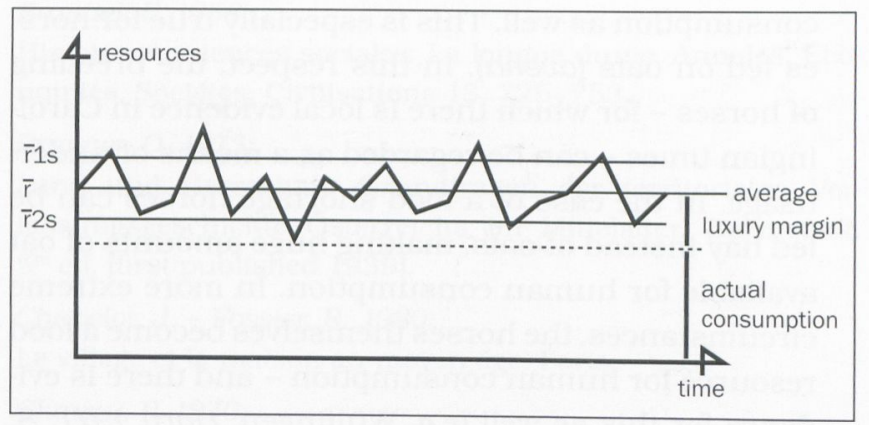

Fig. 9. The logic of under-usage (after Müller-Herold/Sieferle 1996).

conceptual level. In practice the interplay of a bundle of resources and their variations is so complex that the total minimum variation is more of a band than a line. A smooth buffer of basic usage is more appropriate than a strict limitation.

For Carolingian times four such smooth buffers of usage may exemplarily be presented:

- The Christian prohibition of labour on Sundays and Holy Days amounts to at least one hundred days per year (Grotefend 1892; Kellner 1911, esp. 12-17). This prohibition on labour during these days was strictly enforced in Carolingian legislation and efficiently reduced working power and thus resulted in underproductivity for the benefit of satisfying spiritual needs, but could easily be remobilised, if necessary.

- Dietary prohibitions or restrictions of meat and food more generally lower the working power only indirectly, but such prohibitions immediately reduce the need for food resources. Thus it makes sense on an ecological level that Lent is just in early spring, when there is the most critical point of food supply in the annual cycle (Fig. 5). Moreover, from the point of resource-usage the prohibition of meat is especially efficient, as on the calorie level meat is a very inefficient kind of food production.

While these two buffers result in under-usage of resources, two more buffers can apply restrictions to the operation of resources, when necessary.

- Restrictions of use on certain areas especially applied to forests which were reserved for noble hunting (Bannwälder). These areas could not be turned to farming in the short term, while they also offered a bulk of edibles. If things turned to the bad, forests could provide a remarkable resource of potential agricultural land in the long term.

- While the prohibition of meat is especially useful on the calorie-balance of production, cattle, sheep and pigs exploiting resources (grasland and woods) that humans could not feed on directly and thus are widening the range of resources. The opposite is true, if animals are fed on fodder that is suitable for human 
consumption as well. This is especially true for horses fed on oats (avena). In this respect, the breeding of horses - for which there is local evidence in Carolingian times - can be regarded as a means of underusage. In the case of a food shortage horses can be fed hay instead of oats, making huge amounts of oat available for human consumption. In more extreme circumstances, the horses themselves become a food resource for human consumption - and there is evidence for this as well (e.g. Wülfingen: Hartl 1971, 8; Holzheim near Fritzlar: Donat 2002, 500). As horses were rarely used for traction in Carolingian times (Kuchenbuch 1978, 72f.; Hägermann 1991, 397-400; Fichtenau 1994, 440; Verhulst 2002, 67f.) their destruction for human consumption removed a huge prestigious capital, but one that had little agrarian value. We may conclude that horses are the prototype of a luxury margin in a subsistence economy.

\section{The mentalities of subsistence}

The last four points - prohibition of labour, dietary prohibitions, restriction of land use, and breeding of luxury-horses - generate a flexible band of under-usage. None of them is motivated primarily by economics, but all are cultural norms and practices. As Dieter Groh points out, an economic system is not only a rational mode of working, but is founded in social values and paradigms, in a 'social logic', in mentalities (Groh 1992, esp. 60f.; cf. Duby 1973, 64). Economy is - to use the term of Karl Polanyi - embedded in society (Polanyi 1944; Granovetter 2000). Contrary to any proclamations of the New Economists, an economic system cannot be thought outside the framework of the social system and is basically governed by contemporary mentalities of society. Earlier in this paper we already came across such a mentality with Charlemagne's capitulary, stating that all landlords have to feed their familiae. This is less a calculation of economy, but an act of Christian mercy really appropriate to the emperor of the West (Verhulst 2002, 125). Medieval economy is embedded in a Christian society. Christian moral obligations do not necessitate, but enable a completely different, nonmarket-based, subsistence economy.

In summary, Henri Pirenne was in some sense correct- at least for Southern Germany: The manorial system of Carolingian times was a closed agrarian economy based on the manorial system without markets. It was directed by its own economic logic aimed at avoidance of ruin, risk minimization and stability. With respect to the cultural achievements and high social stability of the Carolingian empire it seems that this was not a disaster but an advantage.

\section{Summary}

Normally the economic history of the Carolingian period is analysed according to criteria of a market economy. This economic system is - mostly unreflected - regarded as „natural“ human behaviour. The economic crisis of the last two years, however, has opened possibilities to sketch different economic systems positively as well.

This paper attempts to sketch the Carolingian economy of southern Germany as a subsistence economy according to Marshall Sahlins, Dieter Groh and others. Generally this economic system is not oriented towards growth, but towards stability. It is based on strategies of avoiding risk e.g. by diversification of ressources, space and time and by reallociation via storage and transport. All these elements can plausibly be shown for the Carolingian period of southern Germany. Moreover contemporary mentality seems to be apt for embedding a subsistence economy.

\section{Zusammenfassung}

Die Wirtschaftsgeschichte des älteren Mittelalters wird in der Regel nach den Kriterien einer Marktökonomie analysiert, die - zumeist unreflektiert - als unatürliches" menschliches Verhalten erscheint. Die Wirtschaftskrise der vergangenen zwei Jahre hat nun den Freiraum geschaffen, auch andere ökonomische Systeme als erfolgreiche Verhaltensmuster zu denken.

Dieser Beitrag versucht, die Ökonomie der Karolingerzeit in Süddeutschland als Subsistenzsystem zu entwerfen, wie es von Marshall Sahlins, Dieter Groh und anderen konzipiert wurde. Diese Wirtschaftsweise ist nicht wachstums- sondern stabilitätsorientiert und basiert im Wesentlichen auf Strategien der Risikominimierung, z.B. durch Diversifikation von Ressourcen, Raum und Zeit sowie der Re-Allokation durch Lagerung und Transport. Alle diese Elemente lassen sich für die karolingische Epoche Süddeutschlands plausibel machen. Zudem erscheint die zeitgenössische Mentalität geeignet, eine Subsistenzökonomie einzubetten.

\section{Résumé}

L'histoire économique de l'époque carolingienne est habituellement analysée selon les critères d'une économie de marché, qui - la plupart du temps sans se baser sur une réflexion approfondie - est perçue comme un comportement humain non naturel. La crise économique des deux années passées a créé un nouvel espace libre, dans lequel d'autres systèmes économiques peuvent dorénavant eux aussi être considérés comme prometteurs. 
La contribution présente se propose d'envisager l'économie de l'époque carolingienne du sud de l'Allemagne comme un système de subsistance ainsi qu'il fut conçu par Marshall Sahlins, Dieter Groh et d'autres.

Cette forme d'économie n'est pas orientée vers la croissance, mais vers la stabilité. Elle repose principalement sur des stratégies de minimisation de risques, tels que la diversification de ressources, d'espaces et de temps, ainsi que la ré-allocation par le magasinage et les transports. Tous ces éléments semblent, selon les indicateurs, avoir existés dans le sud de l'Allemagne à l'époque carolingienne. En outre, la mentalité contemporaine semble propice à intégrer une économie de subsistance.

\section{Traduction: Eleonore Pape}

\section{Bibliography}

Annales regni Francorum:

Annales regni Francorum qui dicuntur Annales Laurissenses maiores et Einhardi; ed. Kurze, F. Monumenta Germaniae historica. Scriptores rerum Germanicarum in usum scholarum ex Monumentis Germaniae historicis separatim editi. Hannover 1865.

\section{Capitulare Niumagae:}

Capitulare missorum Niumagae datum; ed. Boretius, A. Monumenta Germaniae historica. Capitularia regum Francorum 1. Hannover 1883, 130-132.

Abel, W. 1967:

Geschichte der deutschen Landwirtschaft vom frühen Mittelalter bis zum 19. Jahrhundert. Deutsche Agrargeschichte 2. Stuttgart, $2^{\text {nd }}$ ed.

\section{Adam, H. 1996:}

Das Zollwesen im fränkischen Reich und das spätkarolingische Wirtschaftsleben. Ein Überblick über Zoll, Handel und Verkehr im 9. Jahrhundert. Vierteljahrschrift für Sozial- und Wirtschaftsgeschichte Beihefte 126. Stuttgart.

Berghaus, P. 1987:

Wirtschaft, Handel und Verkehr der Karolingerzeit im Licht numismatischen Materials, in: Düwel, K. - Jankuhn, H. Siems, H. - Timpe, D. (ed.): Untersuchungen zu Handel und Verkehr der vor- und frühgeschichtlichen Zeit in Mittel- und Nordeuropa 4. Der Handel der Karolinger- und Wikingerzeit. Abhandlungen der Akademie der Wissenschaften in Göttingen. Philologisch-Historische Klasse 3.156. Göttingen, 67-85.

\section{Bleiber, W. 1982:}

Grundherrschaft und Markt zwischen Loire und Rhein während des 9. Jahrhunderts. Untersuchungen zu ihrem wechselseitigen Verhältnis. Jahrbuch für Wirtschaftsgeschichte 105-135.

Brather, S. 2001:

Archäologie der westlichen Slawen. Siedlung, Wirtschaft und Gesellschaft im früh- und hochmittelalterlichen Ostmitteleuropa. Ergänzungsbände zum Reallexikon der Germanischen Altertumskunde 30. Berlin - New York.
Braudel, F. 1958:

Histoire et sciences sociales. La longue durée. Annales. Économies, Sociétés, Civilisations 13, 725-753.

Brunner, O. 1973:

Land und Herrschaft. Grundfragen der territorialen Verfassungsgeschichte Österreichs im Mittelalter. Darmstadt, $5^{\text {th }}$ ed. [first published 1939].

Chapelot, J. - Fossier, R. 1980:

Le village et la maison au moyen âge. Paris.

Chaunu, P. 1970:

La civilisation de l'Europe classique. Les Grandes Civilisation 5. Paris.

Colson, E. 1979:

In good years and bad: food strategies of self-reliant societies. Journal of Anthropological Research 35.1, 18-29.

Delatouche, R. 1977:

Regards sur l'agriculture aux temps carolingiens. Journal des Savants, 73-100.

Devroey, J.-P. 1979:

Les services de transport à l'abbaye de Prüm au IXe siècle. Revue du Nord 61, 543-569 [I am referring to the reprint in: Devroey, J.-P.: Études sur le grand domaine carolingien. Collected Studies Series CS391. Aldershot - Brookfield 1993].

Devroey, J.-P. 1985:

Réflexions sur l'économie des premiers temps carolingiens (768-877): Grands domaines et action politique entre Seine et Rhin. Francia 13, 475-488 [I am referring to the reprint in: Devroey, J.-P.: Études sur le grand domaine carolingien. Collected Studies Series CS391. Aldershot - Brookfield 1993].

Devroey, J.-P. 1987:

Units of measurement in the early medieval economy: The example of Carolingian food rations. French history 1.1, 68-92 [I am referring to the reprint in: Devroey, J.-P.: Études sur le grand domaine carolingien. Collected Studies Series CS391. Aldershot - Brookfield 1993].

Devroey. J.-P. 2006:

Puissants et misérables. Système social et monde paysan dans l'Europe des Francs (VIe-IXe siècles). Académie Royale de Belgique. Mémoire de la Classe des Lettres Collection in- $8^{\circ}$ 3e serie 40 . Bruxelles.

Diepolder, G. 2000:

Archäologie am Holzweg oder wie groß waren große Höfe im frühen Mittelalter? Bemerkungen zum Buch von Klaus Schwarz über Fernwege und Ackerfluren im Alpenvorland. Bayerische Vorgeschichtsblätter 65, 227-237.

Dilcher, G. 1985:

Marktrecht und Kaufmannsrecht im Frühmittelalter, in: Düwel, K. - Jankuhn, H. - Siems, H. - Timpe, D. (ed.): Untersuchungen zu Handel und Verkehr der vor- und frühgeschichtlichen Zeit in Mittel- und Nordeuropa 3. Der Handel des frühen Mittelalters. Abhandlungen der Akademie der Wissenschaften in Göttingen. Philologisch-Historische Klasse 3.150. Göttingen, 392-417.

\section{Doehaerd, R. 1971:}

Le haut moyen âge occidental. Economies et sociétés. Nouvelle Clio 14. Paris. 
Donat, K. 2002:

Die Tierfunde aus der Wüstung Holzheim, in: Wand, N. (ed.): Holzheim bei Fritzlar. Archäologie eines mittelalterlichen Dorfes. Kasseler Beiträge zur Vor- und Frühgeschichte 6. Rahden/Westf., 497-510.

Duby, G. 1962:

Léconomie rurale et la vie des campagnes dans l'occident médiéval (France, Angleterre, Empire, IXe-XVe siècles). Essay de synthèse et perspectives de recherches. Paris.

Duby, G. 1973:

Guerriers et paysans. VII-XIIe siècle. Premier essor de l'économie européenne. London [I am referring to the German edition: Krieger und Bauern. Die Entwicklung der mittelalterlichen Wirtschaft und Gesellschaft bis um 1200. Frankfurt am Main 1984].

Ebersbach, R. 2002:

Von Bauern und Rindern. Eine Ökosystemanalyse zur Bedeutung der Rinderhaltung in bäuerlichen Gesellschaften als Grundlage zur Modellbildung im Neolithikum. Basler Beiträge zur Archäologie 15. Basel.

Elmshäuser, K. - Hedwig, A. 1993:

Studien zum Polyptychon von Saint-Germain-des-Prés. Köln - Weimar - Wien.

Fichtenau, H. 1994:

Lebensordnungen des 10. Jahrhunderts. Studien über Denkart und Existenz im einstigen Karolingerreich. München; $2^{\text {nd }}$ ed. [first published 1984].

Fossier, R. 1981:

Les tendances de l'économie: Stagnation ou croissance? in: Nascita dell'Europa ed Europa carolingia: Un'equazione da verificare. Settimane di Studio del Centro Italiano di Studi sull'Alto Medioevo 27. Spoleto, 261-274/290.

Francovich, R. - Hodges, R. 2003:

Villa to village. The transformation of the Roman countryside in Italy, c. 400-1000. Duckworth Debates in Archaeology. London.

Gast, M. - Sigaut, F. (ed.) 1971-1981:

Les techniques de conservation des grains à long terme. $\mathrm{Pa}-$ ris.

\section{Goetz, H.-W. 1987:}

Herrschaft und Raum in der frühmittelalterlichen Grundherrschaft. Annalen des Historischen Vereins für den Niederrhein 190, 7-33.

Goetz, H.-W. 2001:

Frühmittelalterliche Grundherrschaften und ihre Erforschung im europäischen Vergleich, in: Borgolte, M. (ed.): Das europäische Mittelalter im Spannungsbogen des Vergleichs. Zwanzig internationale Beiträge zu Praxis, Problemen und Perspektiven der historischen Komparatistik. Europa im Mittelalter. Abhandlungen und Beiträge zur historischen Komparatistik 1. Berlin, 65-87.

Granovetter, M. S. 2000:

Ökonomische Institutionen als soziale Konstruktionen - ein Analyserahmen, in: Bögenhold, D. (ed.): Moderne amerikanische Soziologie. Stuttgart 199-217.

Grierson, P. 1959:

Commerce in the dark ages: A critique of the evidence. Transactions of the Royal Historical Society $5^{\text {th }}$ series 9, 123-140.
Grierson P. - Blackburn, M. 1986:

Medieval European coinage. With a catalogue of the coins in the Fitzwilliam Museum, Cambridge 1. The early middle ages $\left(5^{\text {th }}-10^{\text {th }}\right.$ centuries). Medieval European Coinage 1 . Cambridge - New York - Melbourne - Madrid.

Groh, D. 1992:

Strategien, Zeit und Ressourcen. Risikominimierung, Unterproduktivität und Mußepräferenz - die zentralen Kategorien von Subsistenzökonomien, in: Groh, D.: Anthropologische Dimensionen der Geschichte. Frankfurt am Main, 54-113.

Grotefend, H. 1892:

Zeitrechnung des deutschen Mittelalters und der Neuzeit 2. Kalender der Diöcesen Deutschlands, der Schweiz und Skandinaviens. Hannover.

Hägermann, D. 1991:

Technik im frühen Mittelalter zwischen 500 und 1000, in: Hägermann, D. - Schneider, H.: Landbau und Handwerk. 750 v. Chr. bis 1000 n.Chr. Propyläen Technikgeschichte 1. Berlin, 315-505.

Haidle, M. N. 1997:

Mangel - Krisen - Hungersnöte? Ernährungszustände in Süddeutschland und der Nordschweiz vom Neolitikum bis ins 19. Jahrhundert. Urgeschichtliche Materialhefte 11. Tübingen.

Halstead, P. - O'Shea, J. (ed.) 1989:

Bad year economics. Cultural responses to risk and uncertainty. New Directions in Archaeology. Cambridge - New York - Port Melbourne - Madrid - Cape Town.

Hardt, M. 2008a:

Von der Subsistenzwirtschaft zur marktorientierten Produktion von Getreide: der hochmittelalterliche Wandel der Agrarstruktur in den westslawischen Gebieten, in: Herrmann, B. (ed.): Beiträge zum Göttinger Umwelthistorischen Kolloquium 2007-2008. Graduiertenkolleg Interdisziplinäre Umweltgeschichte. Göttingen, 87-116.

Hardt, M. 2008b:

Fernhandel und Subsistenzwirtschaft. Überlegungen zur Wirtschaftsgeschichte der frühen Westslawen, in: Ludwig, U. - Schilp, Th. (ed.): Nomen et Fraternitas. Festschrift für Dieter Geuenich. Ergänzungsbände zum Reallexikon der Germanischen Altertumskunde 62. Berlin - New York, 741-763.

Hartl, M. 1971:

Die Tierknochen aus der Wüstung Wülfingen I. Die Nichtwiederkäuer. Unpublished PhD-thesis. München.

Hocquet, J.-C. 1985:

Le pain, le vin et le juste mesure à table des moines carolingiens. Annales. Economies, Sociétés, Civilisations 3, 661-686.

Hodges, R. 1989:

Dark age economics. The origins of towns and trade A.D. 600-1000. London; $2^{\text {nd }}$ ed. [first published 1982].

Hodges, R. 2000:

Towns and trade in the age of Charlemagne. Duckworth Debates in Archaeology. London.

Hodges, R. - Whitehouse, D. 1983:

Mohammed, Charlemagne \& the origins of Europe. Archaeology and the Pirenne thesis. Ithaca. 


\section{Irsigler, F. 1989:}

Grundherrschaft, Handel und Märkte zwischen Maas und Rhein im frühen und hohen Mittelalter, in: Flink, K. - Janssen, W. (ed.): Grundherrschaft und Stadtentstehung am Niederrhein. Klever Archiv 9. Kleve, 52-78.

\section{Kellner, K. A. H. 1911:}

Heortologie oder die geschichtliche Entwicklung des Kirchenjahres und der Heiligenfeste von den ältesten Zeiten bis zur Gegenwart. Freiburg, $3^{\text {rd }}$ ed.

Kuchenbuch, L. 1978:

Bäuerliche Gesellschaft und Klosterherrschaft im 9. Jahrhundert. Studien zur Sozialstruktur der Familia der Abtei Prüm. Vierteljahrschrift für Sozial- und Wirtschaftsgeschichte Beihefte 66. Wiesbaden.

\section{Kuchenbuch, L. 1988:}

Die Klostergrundherrschaft im Frühmittelalter. Eine Zwischenbilanz, in: Prinz, F. (ed.): Herrschaft und Kirche. Beiträge zur Entstehung und Wirkungsweise episkopaler und monastischer Organisationsformen. Monographien zur Geschichte des Mittelalters 33. Stuttgart, 297-343.

Kuchenbuch, L. 1997:

Potestas und utilitas. Ein Versuch über Stand und Perspektiven der Forschung zur Grundherrschaft im 9.-13. Jahrhundert. Historische Zeitschrift 265, 117-146.

Lee, R. 1968:

What hunters do for a living, or, how to make out on scarce ressources, in: Lee, R. - DeVore, I. (ed.): Man the hunter. Chicago, 30-43.

\section{Lohrmann, D. 1988:}

La croissance agricole en Allemagne au haut moyen age, in: La croissance agricole du haut moyen âge. Chronologie, modalités, géographie. Flaran 10. Auch [1990] 103-115.

Mace, R. 1993:

Nomadic pastoralists adopt subsistence strategies that maximise long-term household survival. Behaviorial Ecology and Sociobiology 33, 329-334.

Mauss, M. 1925:

Essai sur le don. Forme et raison de l'échange dans les sociétés archaïques. Paris.

McCormick, M. 2001:

Origins of the European economy. Communications and commerce AD 300-900. Cambridge - New York - Port Melbourne - Madrid/Cape Town.

Minnis, P. E. 1985:

Social adaptation to food stress. A prehistoric southwestern example. Chicago.

Moreland, J. 2000:

Concepts of the early medieval economy, in: Hansen I. L. Wickham, Ch. (ed.): The long eighth century. The Transformation of the Roman World 11. Leiden - Boston - Köln, $1-34$.

Morimoto, Y. 1988:

Etat et perspectives des recherches sur les polyptyques carolingiens. Annales de l'Est 40, 99-149.

Morimoto, Y. 1994:

Autour du grand domaine carolingien: aperçu critique des recherches récentes sur l'histoire rurale du haut moyen age
(1987-1992), in: Verhulst, A.E. - Morimoto, Y. (ed.): Economie rurale et economie urbaine au moyen age. Landwirtschaft und Stadtwirtschaft im Mittelalter. Gent - Fukuoka, 25-79.

Müller-Herold, U. 2000:

Risk management strategies - before hominization and after. Journal of Risk Research 3, 19-30.

Netting, R. McC. 1981:

Balancing on an alp. Ecological change and continuity in a Swiss mountain community. Cambridge - London - New York - New Rochelle - Melbourne - Sydney.

Niemeier, G. 1944:

Gewannfluren. Ihre Gliederung und die Eschkerntheorie. Petermanns Geographische Mitteilungen 90, 57-74.

Pirenne, H. 1933:

La civilisation occidentale au moyen âge du milieu du XVe siècle. Le mouvement économique et sociale. Histoire du Moyen Age 8. Paris [I am referring to the German edition: Sozial- und Wirtschaftsgeschichte Europas im Mittelalter. Tübingen - Basel 1994, $7^{\text {th }}$ ed.].

Pirenne, H. 1937:

Mahomet et Charlemagne. Paris.

Polanyi, K. 1944:

The great transformation. New York.

Preidel, H. 1965:

Handel und Handwerk im frühgeschichtlichen Mitteleuropa. Eine kritische Betrachtung. Adalbert Stifter Verein München Veröffentlichungen der Wissenschaftlichen Abteilung 10. Gräfelfing.

Riché, P. 1963:

La vie quotidienne dans l'empire Carolingien. Paris [I am referring to the German edition: Die Welt der Karolinger. Stuttgart 1981].

Rösener, W. 1989:

Zur Erforschung der frühmittelalterlichen Grundherrschaft, in: Rösener, W. (ed.): Strukturen der Grundherrschaft im frühen Mittelalter. Veröffentlichungen des Max-Planck-Instituts für Geschichte 92. Göttingen, 9-28.

Rösener, W. 1997:

Einführung in die Agrargeschichte. Darmstadt.

Rouche, M. 1973:

La faim à l'époque carolingienne: Essai sur quelques types de rations alimentaires. Revue Historique 508, 295-320.

Sahlins, M. 1968:

Le première société d'abondance. Les Temps Modernes 268, 641-680 [I am referring to the revised and enlarged version: The original affluent society, in: Sahlins, M.: Stone Age economics. London 1972, 1-39].

Schmaedecke, M. 2002:

Zur Kontinuität von Getreidespeichern auf Stützen von vorgeschichtlicher Zeit bis in die frühe Neuzeit, in: Klápště, J. (ed.): The rural house from the migration period to the oldest still standing buildings. Ruralia IV. Památky Archeologické, Supplementum 15. Prague, 134-142.

Schulze, H. K. 2004:

Grundstrukturen der Verfassung im Mittelalter 1. Stammesverband, Gefolgschaft, Lehnswesen, Grundherrschaft. Stuttgart, $4^{\text {th }}$ ed. [first published 1985]. 


\section{Schwarz, K. 1989:}

Archäologisch-topographische Studien zur Geschichte frühmittelalterlicher Fernwege und Ackerfluren im Alpenvorland zwischen Isar, Inn und Chiemsee. Materialhefte zur Bayerischen Vorgeschichte A45. München.

Sieferle, R. P. - Müller-Herold, U. 1996:

Überfluß und Überleben - Ruin und Luxus in primitiven Gesellschaften. Gaia 5, 135-143.

\section{Sieferle R. P. 2002:}

Unsicherheit, Risiko und Ruinvermeidung, in: Winiwarter, V. - Wilfing, H. (ed.): Historische Humanökologie. Interdisziplinäre Zugänge zu Menschen und ihrer Umwelt. Wien, 151196.

\section{Slicher van Bath, B. H. 1960 :}

De agrarische geschiedenis van West-Europa, 500-1850. Utrecht [I am referring to the english version The agrarian history of Western Europe, A.D. 500-1850. London 1963].

Steuer, H. 1999:

Handel und Wirtschaft in der Karolingerzeit, in: Stiegemann, Ch. - Wemhoff, M. (ed.): 799 Kunst und Kultur der Karolingerzeit. Karl der Große und Papst Leo III. in Paderborn. Beiträge zum Katalog der Ausstellung Paderborn 1999. Mainz am Rhein, 406-416.

Störmer, W. 1989:

Frühmittelalterliche Grundherrschaft bayerischer Kirchen (8.-10. Jahrhundert), in: Rösener, W. (ed.): Strukturen der Grundherrschaft im frühen Mittelalter. Veröffentlichungen des Max-Planck-Instituts für Geschichte 92. Göttingen, 370-410.

\section{Strategien 1986:}

Strategien von Subsistenzökonomien - Stratégies des économies de subsistance. Schweizerische Gesellschaft für Wirtschafts- und Sozialgeschichte 5.5. Lausanne.

Suter, P. J. - Schibler, J. 1996:

Ernährung während der Jungsteinzeit am Bielersee: Modelle und Hypothesen, in: Beier, H.J. (ed.): Studien zum Siedlungswesen im Jungneolithikum. Beiträge zur Ur- und Frühgeschichte Mitteleuropas 10. Weissbach, 23-42.

Toubert, P. 1988:

La part du grand domaine dans le décollage économique de l'Occident (VIIIe-Xe siècles), in: La croissance agricole du haut moyen âge. Chronologie, modalités, géographie. Flaran 10. Auch [1990], 53-86.
Uhlig, H. (ed.) 1967:

Flur und Flurformen - Types of field patterns - Le finage agricole et sa structure parcellaire. Materialien zur Terminologie der Agrarlandschaft - Basic Material for the Terminology of the Agricultural Landscape - Matériaux pour la Terminologie du Paysage Agraire 1. Giessen.

Verhulst, A. E. 1965:

Karolingische Agrarpolitik: Das Capitulare de Villis und die Hungersnöte von 792/93 und 805/06. Zeitschrift für Agrargeschichte und Agrarsoziologie 13, 175-189.

Verhulst, A. E. 1983:

La diversite du regime domanial entre Loire et Rhin a l'epoqie carolingienne, in: Janssen, W. - Lohrmann, D. (ed.): Villa curtis - grangia. Landwirtschaft zwischen Loire und Rhein von der Römerzeit zum Hochmittelalter. Beihefte der Francia 11. München - Zürich, 133-148.

Verhulst, A. E. 2002:

The Carolingian economy. Cambridge - New York - Port Melbourne - Madrid - Cape Town.

Wickham, C. 1990:

European forests in the early middle ages: Landscape and land clearance, in: Lambiente vegetale nell'alto medioevo. Settimane di Studio del Centro Italiano di Studi sull'Alto Medioevo 37. Spoleto, 479-548 [I am referring to the reprint in: Wickham, Ch.: Land and power. Studies in Italian and European social history, 400-1200. London 1994, 155-199].

Wickham, C. 1992:

Problems of comparing rural societies in early medieval Western Europe. Transactions of the Royal Historical Society $6^{\text {th }}$ series $2,221-246$ [I am referring to the reprint in: Wickham, Ch.: Land and power. Studies in Italian and European social history, 400-1200. London 1994, 201-226].

Wickham, C. 1994:

Land and power. Studies in Italian and European social history, 400-1200. London.

Wickham, C. 2005:

Framing the early middle ages. Europe and the Mediterranean 400-800. Oxford.

Ziegelmayer, G. 1988:

Die Bajuwaren aus anthropologischer Sicht, in: Dannheimer, H. - Dopsch, H. (ed.): Die Bajuwaren. Von Severin bis Tassilo 488-788. S.1., 249-257. 